\title{
Å angripe egen kropp
}

Selvskade forekommer hyppig (1). I en norsk undersøkelse rapporterte nærmere $7 \%$ at de det foregående året hadde skadet seg selv med vilje, enten med eller uten suicidal intensjon (2). Mange leger møter disse pasientene. I en artikkel i dette nummeret forteller Kristin Ribe om hvordan hun er blitt møtt av helsepersonell etter å ha skadet seg selv: «Er du her igjen, ta deg sammen!» «Du må slutte, nå har jeg stått her og sydd deg i to og en halv time, det er fullt av folk som venter, du kan ikke holde på sånn» (3). Slike uttalelser er nok dessverre ikke helt sjeldne. Det er lett å forstå at vi som leger blir oppgitte, frustrerte eller fortvilte i møte med noe som kan oppleves som uforklarlig eller irrasjonelt. Hvorfor skader man egen kropp med vilje? Å møte disse pasientene er vanskelig, og hvordan vi gjør det er en test på egen profesjonalitet.

I dette og neste nummer av Tidsskriftet omtales en rekke aspekter ved selvskading. Sommerfeldt \& Skårderud gjennomgår definisjoner, forekomst, risikofaktorer og selvskadingens funksjoner (4), og Mehlum \& Holseth tar for seg utredning og behandling (5). Selvskading forbundet med personlighetsforstyrrelser, spiseforstyrrelser og toppidrett blir omtalt i egne artikler i temaserien. I tillegg presenteres pasienthistorier og kulturelle uttrykk i skjønnlitteratur og film.

Selvskading er et heterogent fenomen. Selv om det er vanlig, vet vi lite om det, og forskningsfeltet er relativt nytt. Et sentralt problem er at begrepet kan romme så mangt. Selvskading har ulik alvorlighetsgrad og forekommer både med og uten suicidal intensjon. Noen skader seg ofte, for andre er det et engangstilfelle. Noen kutter eller risper, andre slår, biter eller brenner, mens noen svelger ufordøyelige stoffer eller tar overdoser. Hva som er hensiktsmessige definisjoner, diskuteres fortsatt.

I psykiatrien knyttes selvskading ofte til spesifikke populasjoner, som fengselsinnsatte eller psykisk utviklingshemmede (6), men i de senere årene er fenomenet blitt synlig i ungdomskulturen generelt. Det finnes også noe empiri for en faktisk økning i forekomst (4). Det er vanlig å oppfatte selvskading som en smittsom praksis. Både hos jenter og gutter er det vist sammenheng mellom selvskadende atferd og selvskading blant venner $(2,7)$. Mediene bør ha en bevisst holdning til oppslag om selvskading. I de senere årene har flere kjendiser som Angelina Jolie og Johnny Depp fortalt om egen selvskading. Pressens vær varsom-plakat nevner ikke selvskading spesielt, men inneholder et eget punkt om selvmord og selvmordsforsøk. I 2005 ble dette punktet endret fra at man som hovedregel ikke skulle omtale selvmord eller selvmordsforsøk til at man skal være varsom ved slik omtale. Med Internett har man fått en ny dimensjon med bl.a. chatterom og blogger om selvskading. Slike nettsteder har møtt mye kritikk. Enkelte etterlyser en bredere debatt der brukernes synspunkter tas med (8). Det er også et stort potensial for konstruktiv bruk av Internett.

Selvskading forstås gjerne som et resultat av vansker med å regulere følelser og å sette ord på følelser. For Ribe var det å kutte seg en «måte å gråte på». Den psykiske smerten uttrykkes ved å skade egen kropp. Dette er en form for dysfunksjonell mestring som kan gi kortvarig lindring av indre smerte. Selvskading kan også være en måte å straffe seg selv på eller være knyttet til uvirkelighetsfølelse.
I noen tilfeller kan selvskading være et signal til omgivelsene, men flere er kritiske til en allmenn holdning om at selvskading dreier seg om å få oppmerksomhet. Mange skammer seg over atferden og forsøker å skjule den (4). I helsevesenet har det vært vanlig å oppfatte selvskadere som manipulative (5). Studier indikerer at kursing kan endre holdninger hos helsepersonell og andre. Leger trenger kunnskap om selvskading for å kunne møte pasientene på en profesjonell måte. Det er vårt håp at Tidsskriftets temaserie kan være et bidrag til dette.

Pasienter med gjentatt selvskading knyttet til alvorlige psykiske problemer bør som regel henvises til spesialisthelsetjenesten. Ulike psykoterapeutiske behandlingsformer, som dialektisk atferdsterapi og mentaliseringsbasert terapi, kan ha effekt (5). I praksis er det lang ventetid. Fastlegen har en viktig rolle som støttespiller, til å motivere til behandling og koordinere tilbudet til pasienten. Mye kartlegging kan finne sted i primærhelsetjenesten i påvente av spesialisthjelp. Fastlegenes møte med pasienter som skader seg er spesielt krevende i legevaktsituasjoner. Man er presset på tid og kjenner kanskje ikke pasienten fra før. Like fullt bør man kartlegge bakgrunnen for selvskaden, vurdere selvmordsfare, om pasienten allerede er i et behandlingsopplegg og hvorvidt innleggelse er nødvendig. Og med enkle grep kan man vise forståelse og respekt, slik legevaktlegen bekreftet Ribes smerte med ordene: «Jeg ser du har hatt det vanskelig» (3).

\section{Siri Lunde}

siri.lunde@legeforeningen.no

Erlend Hem

erlend.hem@medisin.uio.no

Siri Lunde (f. 1979) er cand.med. og medisinsk redaktør i Tidsskriftet.

Erlend Hem (f. 1970) er dr.med., førsteamanuensis i medisinske atferdsfag ved Universitetet i Oslo og medisinsk redaktør i Tidsskriftet.

De to har sammen redigert Tidsskriftets serie om selvskading.

Oppgitte interessekonflikter: Ingen

\section{Litteratur}

1. Madge N, Hewitt A, Hawton K et al. Deliberate self-harm within an international community sample of young people: comparative findings from the Child \& Adolescent Self-harm in Europe (CASE) Study. J Child Psychol Psychiatry 2008: 49: $667-77$.

2. Ystgaard M, Reinholdt NP, Husby J et al. Villet egenskade blant ungdom. Tidsskr Nor Lægeforen 2003; 123: 2241-5.

3. Ribe K. Legen som skalv på hendene mens han sydde. Tidsskr Nor Legeforen 2009; 129: 780.

4. Sommerfeldt B, Skårderud F. Hva er selvskading? Tidsskr Nor Legeforen 2009; 129: $754-8$.

5. Mehlum L, Holseth K. Selvskading - hva gjør vi? Tidsskr Nor Legeforen 2009; 129: 759-62.

6. Malt UF, Retterstøl N, Dahl AA. Lærebok i psykiatri. 2. utg. Oslo: Gyldendal Akademisk, 2003.

7. Hawton K, Rodham K, Evans E et al. Deliberate self-harm in adolescents: self report survey in schools in England. BMJ 2002: 325: 1207-11.

8. Baker D, Fortune S. Understanding self-harm and suicide websites. A qualitative interview study of young adult website users. Crisis 2008; 29: 118-22. 